\title{
Spinal antinociceptive action of amiloride and its interaction with tizanidine in the rat formalin test
}

\author{
Handong Ouyang MD, Peizong Wang MD, Wan Huang MD, Qiang Li MD, Bilin Nie MD, Weian Zeng MD PhD
}

H Ouyang, P Wang, W Huang, Q Li, B Nie, W Zeng. Spinal antinociceptive action of amiloride and its interaction with tizanidine in the rat formalin test. Pain Res Manag 2015;20(6):321-326.

BACKGROUND: Amiloride has been reported to produce a wide variety of actions, thereby affecting several ionic channels and a multitude of receptors and enzymes. Intrathecal $\alpha_{2}$-adrenergic receptor agonists produce pronounced analgesia, and amiloride modulates $\alpha_{2}$-adrenergic receptor agonist binding and function, acting via the allosteric site on the $\alpha_{2} \mathrm{~A}$ adrenergic receptor.

OBJECTIVES: To investigate the antinociceptive interaction of intrathecal amiloride and the $\alpha_{2}$-adrenoceptor agonist tizanidine using a rat formalin test.

METHODS: Sprague-Dawley rats were chronically implanted with lumbar intrathecal catheters and were tested for paw flinching using formalin injection. Biphasic painful behaviour was recorded. Amiloride, tizanidine or an amiloride-tizanidine mixture was administered $10 \mathrm{~min}$ before formalin injection. To characterize any interactions, isobolographic analysis was performed. The effects of a pretreatment using intrathecally administered yohimbine was also tested.

RESULTS: Intrathecally administered amiloride $(12.5 \mu \mathrm{g}$ to $100 \mu \mathrm{g})$ and tizanidine $(0.5 \mu \mathrm{g}$ to $5 \mu \mathrm{g})$, given separately, produced a significant doserelated suppression of the biphasic responses in the formalin test. Isobolographic analysis revealed that the combination of intrathecal amiloride and tizanidine synergistically reduced phase I and II activities. Intrathecally administered yohimbine antagonized or attenuated the antinociceptive effect of amiloride, tizanidine and the amiloride-tizanidine mixture. Intrathecally administered amiloride synergistically interacts with tizanidine to reduce the nociceptive response in the formalin test, most likely by activating $\alpha_{2}$-adrenoceptors in the spinal cord.

CONCLUSIONS: Although intrathecal tizanidine produced pronounced analgesia, antinociceptive doses of intrathecal tizanidine also produced several side effects, including bradycardia and sedation. Amiloride produced antinociceptive action against the thermal nociceptive test without side effects in rats.

Key Words: $\alpha_{2}$-adrenergic receptor; Amiloride; Formalin test; Spinal cord

A miloride is known to act on pharmacological target sites that are implicated in pain processing by inhibiting targets such as lowthreshold $\mathrm{Ca}^{2+}$ channels at a low concentration (1), $\mathrm{Na}^{+} / \mathrm{Ca}^{2+}$ exchange systems at a higher concentration (2), $\mathrm{Na}^{+} / \mathrm{H}^{+}$exchangers (2), biosynthetic pathways for proinflammatory cytokines (3), ATPsensitive $\mathrm{K}^{+}$channels (4), adenosine $\mathrm{A}_{1}$ receptors (5), the gammaaminobutyric acid-A receptor complex (6) and $\mathrm{H}^{+}$-gated cation channels (7). Additionally, amiloride has proven to be a useful drug for studying the molecular mechanisms involved in $\mathrm{Na}^{+}$translocation across cell membranes (8). The systemic, spinal or supraspinal administration of amiloride causes dose-related antinociception, as indicated by assessing acetic acid-induced writhing and formalin- and capsaicininduced licking (9). The mechanism by which amiloride produces its antinociceptive action appears to be unrelated to nonspecific toxic

\author{
L'effet antinociceptif de l'amiloride sur la moelle \\ épinière et son interaction avec la tizanidine dans le \\ test au formol chez des rats
}

HISTORIQUE : L'amiloride produit un vaste éventail d'effets qui touchent plusieurs canaux ioniques et une multitude de récepteurs et d'enzymes. L'agoniste des alpha-2 récepteurs adrénergiques par voie intrathécale produit une analgésie prononcée, et l'amiloride en module la liaison et la fonction par son action allostérique sur le récepteur alpha-2A adrénergique.

OBJECTIFS : Examiner l'interaction antinociceptive de l'administration par voie intrathrécale d'amiloride et de tizanidine, un agoniste alpha-2 adrénergique, au moyen du test au formol chez des rats.

MÉTHODOLOGIE : Les chercheurs ont implanté un cathéter lombaire à demeure dans l'espace intrathécal de rats Sprague-Dawley et ont vérifié le tressaillement de leur patte au moyen d'une injection de formol. Ils ont consigné l'évolution biphasique de la douleur. Ils leur ont administré de l'amiloride, de la tizanidine ou un mélange d'amiloride et de tizanidine dix minutes avant de leur injecter du formol. Pour caractériser les interactions, ils ont effectué une analyse isobolographique. Ils ont également observé les effets de l'administration préalable de yohimbine par voie intrathécale.

RÉSULTATS : Dans le test au formol, l'amiloride (12,5 $\mu \mathrm{g}$ à $100 \mu \mathrm{g})$ et la tizanidine $(0,5 \mu \mathrm{g}$ à $5 \mu \mathrm{g})$, administrées séparément par voie intrathécale, produisaient une importante suppression des réponses biphasiques liées à la dose. L'analyse isobolographique a révélé que le mélange d'amiloride et de tizanidine par voie intrathécale réduisait les activités de phase I et II. L'administration de yohimbine par voie intrathécale entravait ou atténuait l'effet antinociceptif de l'amiloride, de la tizanidine et du mélange d'amiloride et de tizanidine. L'administration d'amiloride par voie intrathécale a une action synergique sur la tizanidine et en réduit la réponse nociceptive dans le test au formol, probablement en activant les alpha-2 adrénorécepteurs de la moelle épinière.

CONCLUSIONS : Même si la tizanidine par voie intrathécale produisait une analgésie prononcée, des doses antinociceptives s'associaient à plusieurs effets secondaires, y compris la bradycardie et la sédation. L'amiloride produisait un effet antinociceptif sur le test nociceptif thermique, sans provoquer d'effets secondaires chez des rats.

effects, such as muscle relaxation or sedation in animals, and appears to be associated, at least in part, with the interference of homeostasis and function of the somatosensory system. Thus, amiloride or its derivatives may be of potential interest in the development of new antihyperalgesic drugs. The $\alpha_{2}$-adrenoceptor agonist is widely used for analgesia and sedation. Intrathecal $\alpha_{2}$-adrenoceptor agonist has been revealed to produce pronounced analgesia (10). Tizanidine is a novel, centrally acting $\alpha_{2}$-adrenoceptor agonist that is available in oral form for the treatment of muscle spasms (11), and also has significant antinociceptive effects without hypotension in rats when administered intrathecally $(12,13)$ or subcutaneously $(14)$. Although tizanidine is associated with a moderate incidence of sedation when administered at effective systemic doses, it is well tolerated clinically, with a low incidence of hemodynamic side effects (15).

${ }^{1}$ Department of Anesthesiology, State Key Laboratory of Oncology in Southern China, Cancer Center, Sun Yat-Sen University, Collaborative Innovation Center for Cancer Medicine, Guangzhou, China

Correspondence: Prof Weian Zeng, 651 Dongfeng RD East, Guangzhou, Guandong, China 510060. Telephone 86-20-87343062,

e-mail zengwa@mail.sysu.edu.cn 


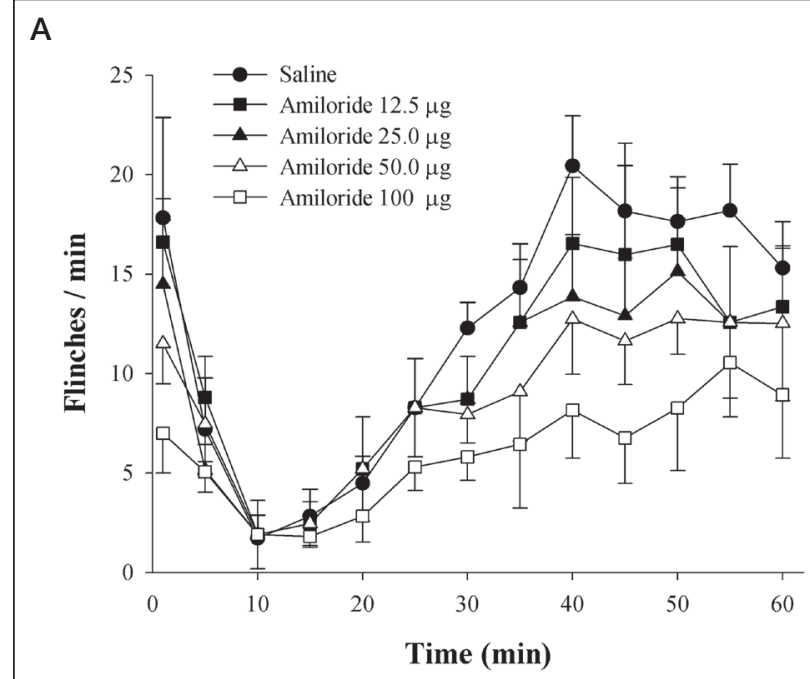

B

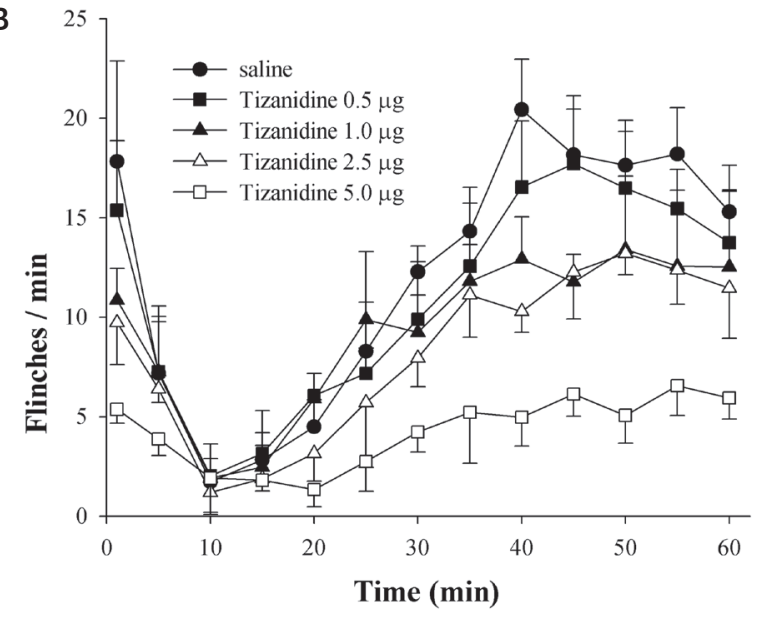

C

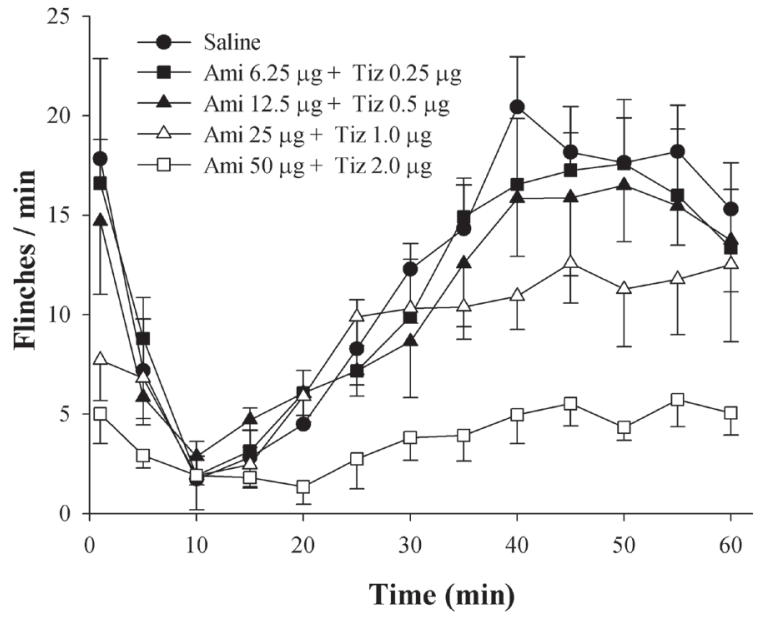

Figure 1) Time-effect curve of intrathecal amiloride (Ami) (A), tizanidine (Tiz) (B) and amiloride and tizanidine combinations (C) administered before formalin. The number of flinches per min is plotted versus the time after the formalin injection into the hindpaw. Each line on the graph represents the mean $\pm S D$ from six rats

In a previous study, we found that the intrathecal administration of amiloride produced significantly dose-dependent antinociception in the thermal tail-flick test, and a synergistic interaction exists between amiloride and morphine or clonidine (16). Leppik and Birdsall (17) revealed that amiloride modulated $\alpha_{2}$-adrenergic receptor agonist binding and function, acting via the allosteric site on the $\alpha_{2} \mathrm{~A}$ adrenergic receptor. Amiloride competes for the agonist binding site on the $\alpha_{2} A$-adrenergic receptor at low concentrations (17). However, no study has investigated whether amiloride produces antinociception via the $\alpha_{2}$-adrenergic receptor against formalin-induced pain.

Drug combinations are an alternative approach used to obtain effective analgesia, while decreasing the incidence and severity of side effects. There has been increasing research in recent years examining drug combinations that produce analgesia in experimental animals, which may be useful in clinical research. The general purposes for using a combination of drugs are to enhance analgesia through either synergism or additive effects, and to reduce the side effects of the drugs by either reducing the dose of each drug or allowing the drugs to interact so that one drug reduces the side effects of the other. To the best of our knowledge, no study has evaluated the effectiveness of the antinociceptive interaction of amiloride and tizanidine in the formalin test. Accordingly, the purpose of the current study was to assess the interaction between intrathecal amiloride and tizanidine in the formalin test.

\section{Animals}

\section{METHODS}

The present research was approved by the Animal Care and Use Committee of Sun Yat-Sen University (Guangzhou, China). Studies were performed using male Sprague-Dawley rats weighing $250 \mathrm{~g}$ to $300 \mathrm{~g}$. Rats were housed individually in a temperature-controlled $\left(21 \pm 1^{\circ} \mathrm{C}\right)$ room with a $12 \mathrm{~h} \mathrm{light/dark} \mathrm{cycle,} \mathrm{and} \mathrm{were} \mathrm{given} \mathrm{ad} \mathrm{libitum}$ access to water and food. All surgical procedures were performed with the rats under intraperitoneally administered $10 \%$ chloral hydrate $(3 \mathrm{ml} / \mathrm{kg}$ to $4 \mathrm{ml} / \mathrm{kg}$ ) anesthesia. Using the method described by Ouyang et al (16), an intrathecal catheter $(\mathrm{PE}-10,8.5 \mathrm{~cm})$ was inserted through an opening in the cisterna magna to the lumbar subarachnoid space. Animals showing neurological deficits after implantation were excluded. After surgery, the animals were allowed to recover for one week before drug administration. Each animal was studied only one time during the experiment. After the experiment, each rat was euthanized with an overdose of pentobarbital, and an injection of $1 \%$ methylene blue was given to confirm the position of the catheter and the likely spread of the injection.

\section{Drugs and injections}

The drugs administered during the experiments were amiloride hydrochloride hydrate (molecular weight [MW] 266.09; Sigma-Aldrich, USA), tizanidine hydrochloride (MW 290.17; Sigma-Aldrich, USA) and yohimbine hydrochloride (MW 390.90; Sigma-Aldrich, USA). All drugs were dissolved in normal saline. Amiloride and tizanidine were each intrathecally administered $10 \mathrm{~min}$ before the formalin test. To assess the dose dependency and time courses of the antinociceptive action of intrathecal amiloride, tizanidine and coadministered amiloride-tizanidine, the animals were randomly assigned to different groups receiving intrathecal injections of different doses of amiloride (12.5 $\mu \mathrm{g}, 25 \mu \mathrm{g}, 50 \mu \mathrm{g}, 100 \mu \mathrm{g})$, tizanidine $(0.5 \mu \mathrm{g}, 1 \mu \mathrm{g}, 2.5 \mu \mathrm{g}, 5 \mu \mathrm{g})$ or amiloride plus tizanidine $10 \mathrm{~min}$ before formalin injection. In the control group, intrathecal saline was given. Yohimbine was intrathecally administered $10 \mathrm{~min}$ before $5 \mu \mathrm{g}$ tizanidine, $100 \mu \mathrm{g}$ amiloride or the dose that resulted in $50 \%$ of the saline response $\left(\mathrm{ED}_{50}\right) / 2$ of amiloride + tizanidine $\mathrm{ED}_{50} / 2$ mixture. The agents were delivered using a microsyringe in a total volume of $10 \mathrm{~mL}$, followed by $10 \mathrm{~mL}$ of saline to flush the catheter.

\section{Formalin test}

For formalin injection, $50 \mathrm{~mL}$ of $5 \%$ formalin was subcutaneously injected into the dorsal surface of the left hindpaw using a 27-gauge needle. Animals were then placed in a clear plexiglas cylinder $(20 \mathrm{~cm} \times 30 \mathrm{~cm})$ for observation. A mirror was placed below the floor (which was made of plexiglas) at a $45^{\circ}$ angle to allow for unencumbered observation during the test. Within 1 min of the injection, the rat exhibited the typical behaviour of this model, ie, holding the 
Intrathecally administered amiloride, tizanidine or their combination in the formalin test

\begin{tabular}{|c|c|c|c|c|c|c|c|c|c|c|}
\hline \multirow[b]{3}{*}{ Group } & \multicolumn{4}{|c|}{ Phase I } & \multicolumn{5}{|c|}{ Phase II } & \multirow[b]{3}{*}{ TFV } \\
\hline & \multicolumn{2}{|c|}{ Amiloride component } & \multicolumn{2}{|c|}{ Tizanidine component } & & \multicolumn{2}{|c|}{ Amiloride component } & \multicolumn{2}{|c|}{ Tizanidine component } & \\
\hline & Intrathecal dose & $\begin{array}{l}\text { Fraction } \\
\text { of } E D_{50}\end{array}$ & Intrathecal dose & $\begin{array}{l}\text { Fraction } \\
\text { of } E D_{50}\end{array}$ & TFV & Intrathecal dose & $\begin{array}{l}\text { Fraction } \\
\text { of } E D_{50}\end{array}$ & Intrathecal dose & $\begin{array}{l}\text { Fraction } \\
\text { of } E D_{50}\end{array}$ & \\
\hline Amiloride & $92.7(69-116)$ & 1.00 & - & - & 1.00 & $103.0(92-116)$ & 1.00 & - & - & 1.00 \\
\hline Tizanidine & - & - & $3.78(3.12-4.40)$ & 1.00 & 1.00 & - & - & $3.76(3.53-3.99)$ & 1.00 & 1.00 \\
\hline $\begin{array}{c}\text { Amiloride + } \\
\text { tizanidine }\end{array}$ & $16.3(10.9-21.9)$ & 0.18 & $0.65(0.43-0.88)$ & 0.17 & 0.35 & $18.8(14.6-22.9)$ & 0.18 & $0.75(0.58-0.92)$ & 0.20 & 0.38 \\
\hline
\end{tabular}

Data presented as effective dose $(\mu \mathrm{g})$ resulting in a $50 \%$ reduction of control response $\left(E D_{50}\right)(95 \%$ Cl) unless otherwise indicated. Total fraction value $($ TFV) $<1$ indicates a synergistic interaction; TFV >1 indicates a antagonistic interaction; TFV=1 indicates an additive interaction.

injected paw slightly above the floor. During this period, spontaneous flinching of the injected paw could also be observed. Flinching was readily discriminated and was characterized as a rapid and brief withdrawing or flexing of the injected paw. Pain-related behaviour was quantified by counting the number of flinches for 1 min periods from $1 \mathrm{~min}$ to $2 \mathrm{~min}$ and $5 \mathrm{~min}$ to $6 \mathrm{~min}$, and then at $5 \mathrm{~min}$ intervals during the period from $10 \mathrm{~min}$ to $60 \mathrm{~min}$ after the formalin injection. Two phases of spontaneous flinching behaviour were observed. An initial acute pain response (phase I, during the 0 min to 6 min interval after the formalin injection) was followed by a relatively short quiescent period, and then by a prolonged tonic response (phase II, beginning approximately $10 \mathrm{~min}$ after the formalin injection). The criteria for exclusion from the study included incomplete formalin injection or excessive bleeding from the injection site.

Motor blockage was graded according to the scale proposed by Langerman et al (18) for rabbits, which was modified to the rat model as follows: 0 = free movement of the hindlimbs without limitation; $1=$ limited or asymmetrical movement of the hindlimbs to support the body and walk; 2 = inability to support the back of the body on the hindlimbs, with detectable movement of the limbs and response to a pain stimulus; and $3=$ total paralysis of the hindlimbs.

\section{Statistical analyses}

In the formalin test, time-response data are presented as the mean $\pm \mathrm{SD}$ per min. The dose-response lines for the phase I and phase II effects were then fitted using least-squares linear regression analysis, and the $\mathrm{ED}_{50}$ and their $95 \% \mathrm{CI}$ were calculated. To calculate the $\mathrm{ED}_{50}$ values for each drug, the number of flinches were converted into a percentage of the control using the following formula:

$$
\% \text { of control }=\frac{\text { Sum of phase I (or II) count with drug }}{\text { Sum of phase I (or II) count, control }} \times 100
$$

Isobolographic analysis for the drug-drug interaction was conducted according to the procedure described by Tallarida et al (19). The method was based on comparisons of doses that were determined to be equieffective. To perform the isobolographic analysis, amiloride and tizanidine were administered in combination as fixed ratios of the equieffective $\mathrm{ED}_{50}$ dose for each drug.

Because no significant differences were observed between the $\mathrm{ED}_{50}$ values for both phases of the formalin test, subsequent experiments were based on one $\mathrm{ED}_{50}$ value to evaluate two phases of the formalin test. Thus, a dose-response curve was constructed from the concurrent delivery of the two routes of administration in a constant dose ratio of $\mathrm{ED}_{50}$ values (amiloride $\mathrm{ED}_{50} / 2+$ tizanidine $\mathrm{ED}_{50} / 2$, amiloride $\mathrm{ED}_{50} / 4+$ tizanidine $\mathrm{ED}_{50} / 4$, amiloride $\mathrm{ED}_{50} / 8+$ tizanidine $\mathrm{ED}_{50} / 8$, amiloride $\mathrm{ED}_{50} / 16+$ tizanidine $\left.\mathrm{ED}_{50} / 16\right)$. The dose-response curve of the combined drugs was used to calculate the actual (experimental) $\mathrm{ED}_{50}$ value and $\mathrm{CI}$. To evaluate the nature of any sitesite antinociceptive interaction between tizanidine and amiloride, isobolograms were drawn by plotting the experimentally determined $\mathrm{ED}_{50}$ value of tizanidine on the $x$ axis and that of amiloride on the $y$ axis, considering the drugs delivered separately and in combination.
The theoretically additive $\mathrm{ED}_{50}$ value, assuming simple additivity, and CI were calculated according to Tallarida (20). To further describe the magnitude of the interaction, a total fraction value was calculated according to the formula:

Total fraction value $=$

$\frac{\mathrm{ED}_{50} \text { dose in combination of drug } 1}{\mathrm{ED}_{50} \text { value for drug } 1 \text { given alone }}+\frac{\mathrm{ED}_{50} \text { dose in combination of drug } 2}{\mathrm{ED}_{50} \text { value for drug } 2 \text { given alone }}$

The fractional values indicated which portion of the single $\mathrm{ED}_{50}$ value was accounted for by the corresponding $\mathrm{ED}_{50}$ value for the combination. Values of approximately 1 indicated an additive interaction, values $>1$ implied an antagonistic interaction and values $<1$ indicated a synergistic interaction. Dose-response data were analyzed using a one-way ANOVA with Bonferroni analysis and were compared with the saline control group. For statistical comparison of the difference between the theoretical additive point and the experimentally derived $\mathrm{ED}_{50}$ value, Student's $t$ tests were used; $\mathrm{P}<0.05$ was considered to be statistically significant.

Individual drug responses

\section{RESULTS}

The subcutaneous injection of formalin into the hindpaw resulted in a biphasic flinching response of the injected paw. The timing or magnitude of the behavioural response did not differ among the control experiments (intrathecal saline $10 \mathrm{~min}$ before formalin; one-way ANOVA; P>0.05); thus, the control experiments were pooled and used as a common control group.

The dose-dependent effects of intrathecal amiloride and tizanidine separately produced a suppression of the formalin-induced behavioural response (Figure 1). The $\mathrm{ED}_{50}$ values of amiloride in phases I and II were $92.7 \mu \mathrm{g}(95 \% \mathrm{CI} 69 \mu \mathrm{g}$ to $116 \mu \mathrm{g})$ and $103.0 \mu \mathrm{g}(95 \% \mathrm{CI} 92 \mu \mathrm{g}$ to $116 \mu \mathrm{g})$, respectively. The $\mathrm{ED}_{50}$ values of tizanidine in phases I and II were $3.78 \mu \mathrm{g}(95 \% \mathrm{CI} 3.12 \mu \mathrm{g}$ to $4.40 \mu \mathrm{g})$ and $3.76 \mu \mathrm{g}(95 \% \mathrm{CI} 3.53 \mu \mathrm{g}$ to $3.99 \mu \mathrm{g})$, respectively.

\section{Isobolographic analyses}

The isobologram of amiloride and tizanidine combined revealed that the experimentally derived $\mathrm{ED}_{50}$ values of amiloride and tizanidine in phase I were $16.3 \mu \mathrm{g}(95 \% \mathrm{CI} 10.9 \mu \mathrm{g}$ to $21.9 \mu \mathrm{g})$ and $0.65 \mu \mathrm{g}(95 \%$ CI $0.43 \mu \mathrm{g}$ to $0.88 \mu \mathrm{g}$ ), respectively. The theoretical additive points of amiloride and tizanidine in phase I were $1.86 \mu \mathrm{g}(95 \% \mathrm{CI} 1.50 \mu \mathrm{g}$ to $2.22 \mu \mathrm{g})$ and $46.58 \mu \mathrm{g}(95 \% \mathrm{CI} 37.5 \mu \mathrm{g}$ to $55.6 \mu \mathrm{g})$, respectively. The experimentally derived $\mathrm{ED}_{50}$ values of amiloride and tizanidine in phase II were $18.8 \mu \mathrm{g}$ (95\% CI $14.6 \mu \mathrm{g}$ to $22.9 \mu \mathrm{g})$ and $0.75 \mu \mathrm{g}$ (95\% CI $0.58 \mu$ g to $0.92 \mu \mathrm{g}$ ), respectively. The theoretical additive points of amiloride and tizanidine in phase II were $1.97 \mu \mathrm{g}(95 \% \mathrm{CI} 1.77 \mu \mathrm{g}$ to $2.12 \mu \mathrm{g})$ and $48.7 \mu \mathrm{g}(95 \% \mathrm{CI} 43.7 \mu \mathrm{g}$ to $53.7 \mu \mathrm{g})$, respectively. The experimentally derived $\mathrm{ED}_{50}$ values decreased below the theoretical dose-additive line, and the CIs of the theoretical additive points and those of the experimental points did not overlap (Figure 2). The total fraction values in phases I and II were 0.35 and 0.38 , respectively (Table 1). These results indicated a significant difference between 


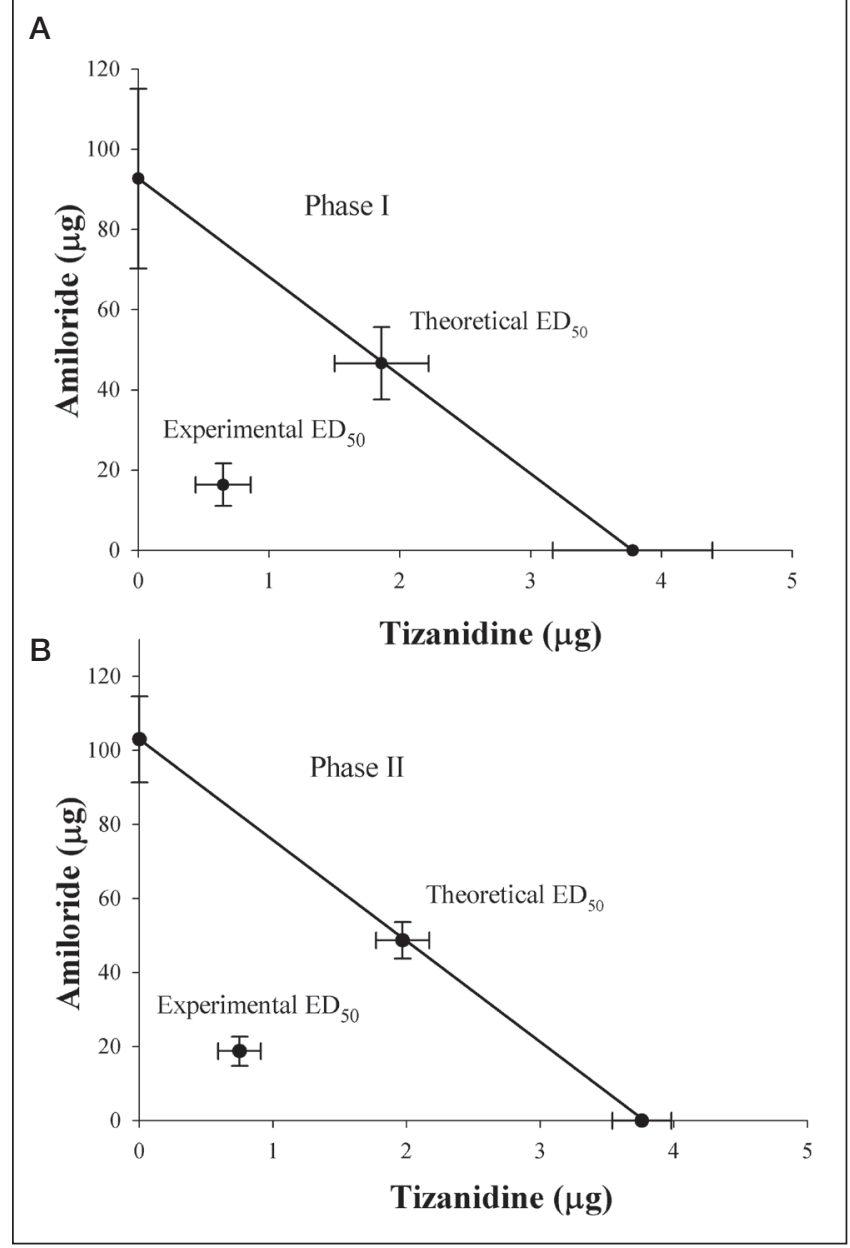

Figure 2) Isobologram revealing the interaction between intrathecal amiloride and tizanidine in phases I and II of the formalin test. The dose that resulted in $50 \%$ of the saline response $\left(E D_{50}\right)$ values of amiloride and tizanidine are plotted on the $x$ - and $y$-axes, respectively. The line connecting the $E D_{50}$ points is the theoretical additive line and the theoretical additive point for the drug combination is shown on the additive line. The experimental $E D_{50}$ value of the combination of the two agents was significantly lower than the theoretical additive value $(P<0.05)$, indicating a synergistic interaction

the experimental $\mathrm{ED}_{50}$ point and the theoretical additive $\mathrm{ED}_{50}$ point $(\mathrm{P}<0.05)$, and a synergistic interaction between amiloride and tizanidine in phases I and II of the formalin test. Intrathecal pretreatment with yohimbine $(20 \mu \mathrm{g})$ antagonized or attenuated the effects of amiloride $(100 \mu \mathrm{g})$, tizanidine $(5 \mu \mathrm{g})$ and the amiloride-tizanidine mixture in phases I and II (Figure 3$)$. Yohimbine $(20 \mu \mathrm{g})$ alone did not show any antinociception in the formalin test in our research (Figure 4).

\section{Other effects}

The assessment of motor functions revealed no differences in scores on the modified scale (see Methods), regardless of whether the observations were made before or after intrathecally administering amiloride or tizanidine during the observation period. Similarly, no motor impairment was observed in the animals after the intrathecal administration of the amiloride and tizanidine combination (Table 2).

\section{DISCUSSION}

There were two important observations in our study. The intrathecal administration of amiloride and tizanidine produced a significant doseantinociceptive effect in the formalin test. Additionally, a synergistic effect was observed between amiloride and tizanidine with regard to spinally mediated formalin pain via the $\alpha_{2}$-receptor.

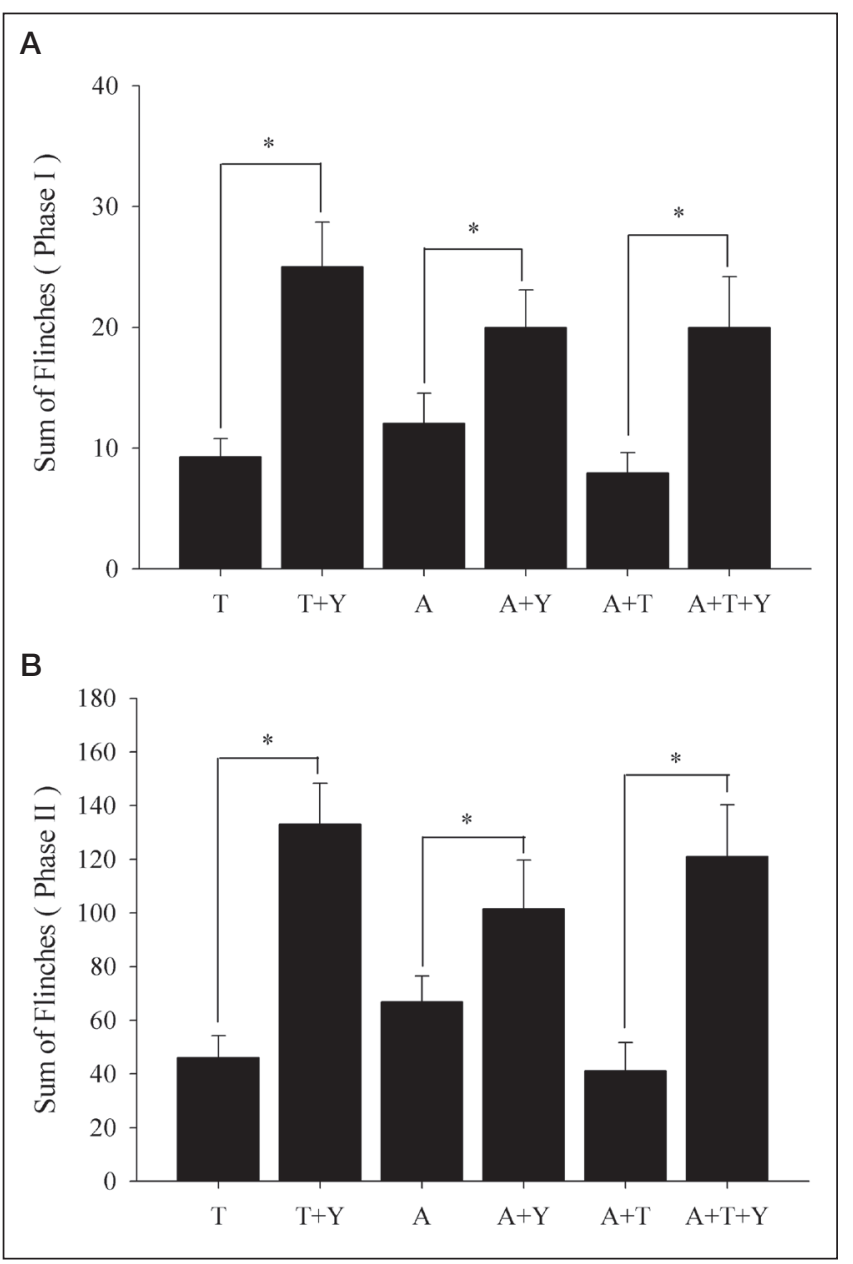

Figure 3) To examine pharmacological antagonism of the effects of amiloride $(\mathrm{A} ; 100 \mu \mathrm{g})$, tizanidine $(\mathrm{T} ; 5 \mu \mathrm{g})$ and amiloride $(50 \mu \mathrm{g})$-tizanidine $(2 \mu \mathrm{g})$, yohimbine $(\mathrm{Y} ; 20 \mu \mathrm{g})$ was intrathecally administered $10 \mathrm{~min}$ before the administration of the agonists. Each bar represents the sum of flinches in phase II (mean $\pm \mathrm{SD})$ from six rats $(* P<0.05)$

Although the mechanisms for amiloride antinociception have not been completely established, several hypotheses have been proposed. Amiloride has been reported to produce a wide variety of actions affecting several ion channels and a multitude of receptors and enzymes $(5,21,22)$, such as by inhibiting $\mathrm{Na}+$ transport in a wide variety of cellular systems and blocking T-type calcium channels (1). The systemic, spinal or supraspinal administration of amiloride at doses that do not cause side effects (motor dysfunction) causes dose-related antinociception, assessed in terms of acetic acid-induced writhing and formalin- and capsaicin-induced licking (9).

Dose-dependent amiloride inhibited acid-induced mechanical hypersensitivity in male mice (23), and reversed both thermal and mechanical hypersensitivity produced by inflammation or skin incision (24). The injection of amiloride was found to significantly attenuate acid-mediated pain, suggesting that amiloride-sensitive acid-sensing ion channels are responsible for a substantial proportion of acidmediated pain (25). The amiloride-sensitive $\mathrm{Na}^{+}$-channel/degenerin family constitutes a group of proteins that is thought to be involved in a wide variety of functions, such as sodium and $\mathrm{pH}$ homeostasis, mechanical stimulus transduction and nociception (26). All of these effects may at least partially contribute to the reported antinociceptive action of amiloride. Leppik and Birdsall (17) revealed that amiloride modulated $\alpha_{2}$-adrenergic receptor agonist binding and function, acting via the allosteric site on the $\alpha_{2} \mathrm{~A}$-adrenergic receptor. Amiloride may have 
TABLE 2

Motor blockage after intrathecally administered amiloride, tizanidine or their combination in the formalin test

\begin{tabular}{|c|c|c|c|c|c|c|c|c|c|c|c|c|c|}
\hline \multirow[b]{2}{*}{ Groups } & \multicolumn{13}{|c|}{ Time, $\min$} \\
\hline & 1 & 5 & 10 & 15 & 20 & 25 & 30 & 35 & 40 & 45 & 50 & 55 & 60 \\
\hline Tizanidine $5.0 \mu \mathrm{g}$ & 0 & 0 & 0 & 0 & 0 & 0 & 0 & 0 & 0 & 0 & 0 & 0 & 0 \\
\hline
\end{tabular}

$0=$ free movement of the hindlimbs without limitation

competed for the agonist binding site on the $\alpha_{2} \mathrm{~A}$-adrenergic receptor at low concentrations (17). However, evidence indicates that local peripheral or intrathecal pretreatment but not post-treatment with amiloride increased long-lasting secondary allodynia and hyperalgesia in both hindpaws in the formalin test (27). The spinal administration of amiloride augmented formalin-induced flinching behaviour. The pronociceptive effect of amiloride observed in the formalin test may be attributable to changes in the intracellular $\mathrm{pH}$ induced by the inhibition of the spinal $\mathrm{Na}^{+} / \mathrm{H}^{+}$exchanger 1 (28). The reason for this discrepancy is unclear, but may be related to the amiloride concentration and dosage because different amiloride concentrations and dosages exert different actions $(1,2)$. In our study, amiloride produced a significant dose-dependent antinociceptive effect in the formalin test during phases I and II, and this effect was partly attenuated by the $\alpha_{2}$-adrenergic blocker yohimbine.

An intrathecal $\alpha_{2}$-adrenoceptor agonist has been shown to produce pronounced analgesia (10). The $\alpha_{2}$-adrenoceptor agonist is widely used for analgesia and sedation. Tizanidine is a novel, centrally acting $\alpha_{2}$-adrenoceptor agonist that is available in an oral form for the treatment of muscle spasms (11), and also has significant antinociceptive effects without hypotension in rats when given intrathecally $(12,13)$ or subcutaneously (14). Tizanidine was injected into the paw and produced a dose-dependent antinociceptive effect against formalin-induced pain. Isobolographic analyses revealed a significant antagonistic interaction in the tizanidine-tramadol combinations (29). Although tizanidine is associated with a moderate incidence of sedation when administered at effective systemic doses, it is well tolerated clinically, with a low incidence of hemodynamic side effects (15). Although oral tizanidine is classified therapeutically as a muscle relaxant, it does not suppress monosynaptic and polysynaptic reflexes when administered intrathecally (12). Previous reports have suggested that tizanidine produced antinociceptive effects in tail-flick tests at dose levels that were considerably lower than those expected to show muscle relaxant action $(12,30)$. These antinociceptive effects were also reversed by the $\alpha_{2}$-adrenergic antagonist yohimbine (12). In the current study, the doses of amiloride and tizanidine used did not show any changes in motor function scores and attenuated both phases of the flinching response, and these actions were antagonized or attenuated by yohimbine administration. This finding indicates that the action of amiloride is at least partly via an $\alpha_{2}$-adrenergic receptor.

The interaction mechanism between the two different types of drugs may be that the different receptors localized on individual primary afferent neurons are coupled to a single class of ion channels. Synergistic interactions can occur when drugs affect different critical points along a common pathway (31). Therefore, the simultaneous activation of a common, second messenger pathway within individual neurons by two different receptors may facilitate the effector mechanisms. Amiloride can modulate $\alpha_{2}$-adrenergic receptor agonist binding and function, acting via the allosteric site on the $\alpha_{2} A$-adrenergic receptor (17). In the current study, the action of the amiloride-tizanidine mixture was antagonized by yohimbine, suggesting that the synergistic effects may be at least partly mediated by $\alpha_{2}$-adrenoceptor, but not by the muscle-relaxant properties or the other pharmacological actions of tizanidine or amiloride. Furthermore, one may conclude that the synergistic effects of amiloride and tizanidine may block these channels. $\mathrm{Na}^{+} / \mathrm{H}^{+}$exchange may be another common pathway for amiloride and

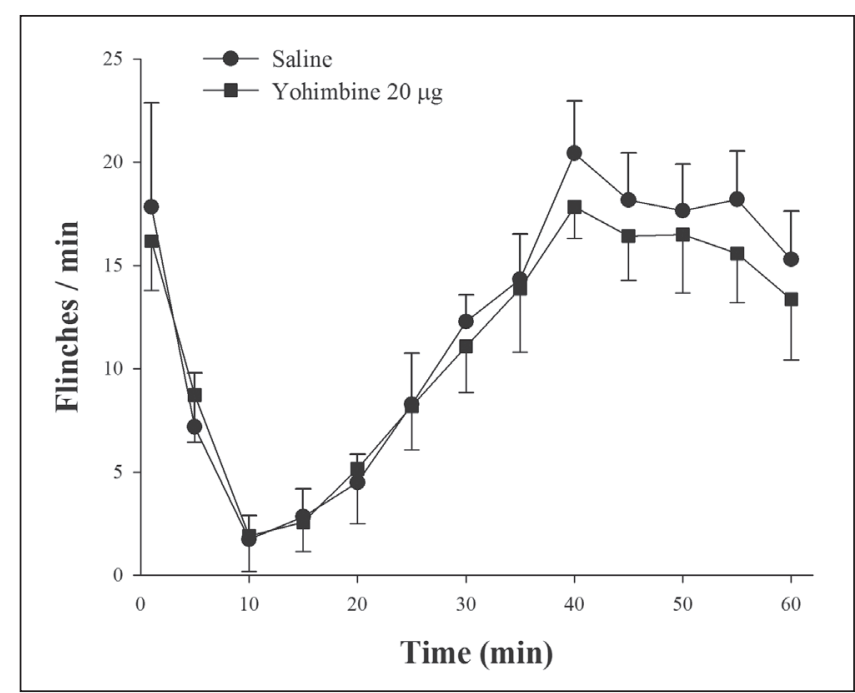

Figure 4) Time-effect curve of the intrathecal administration of $20 \mu \mathrm{g}$ yohimbine before formalin. The number of flinches per min is plotted versus the time after the formalin injection into the hindpaw. Each point on the plot represents the mean \pm SD from six rats

tizanidine $(2,32)$. Whether the pharmacokinetic variables of one drug may be altered by combination with a second drug remains unclear. Although we did not study the redistribution of the intrathecal drugs, Monasky et al (33) reported that spinal $\alpha_{2}$-adrenoceptor agonists did not alter the spinal clearance of other spinal drugs. Therefore, it seems unlikely that the synergistic interaction between tizanidine and amiloride depends on the altered clearance of either drug. As a limitation of the present study, we did not investigate all of the possible mechanisms underlying the observed synergism; this study demonstrated only that the intrathecal administration of amiloride and tizanidine had a synergistic effect against formalin-induced pain in both phases via the $\alpha_{2}$-adrenergic receptor. Additional mechanisms should be investigated, and this type of synergistic interaction in a drug mixture may be useful in clinical pain therapy.

\section{CONCLUSION}

The current study revealed that intrathecal amiloride and tizanidine produce antinociceptive effects in a dose-dependent manner in the formalin test, and that the antinociceptive, synergistic interaction observed between amiloride and tizanidine by isobolographic analysis is at least partly via the action of the $\alpha_{2}$-adrenoceptor in the spinal cord.

DISCLOSURES: The authors have no financial disclosures or conflicts of interest to declare.

ACKNOWLEDGEMENTS: This project was supported by the National Natural Science Foundation of China (Grant No. 81300966, 81271246), the Sci-tech Program Foundation of Guangdong (Grant No.2009B030801161), and the Medical Scientific Research Foundation of Guangzhou (Grant No.2009-YB-172). 


\section{REFERENCES}

1. Tang CM, Presser F, Morad M. Amiloride selectively blocks the low threshold (T) calcium channel. Science 1988;240:213-5.

2. Masereel B, Pochet L, Laeckmann D. An overview of inhibitors of $\mathrm{Na}(+) / \mathrm{H}(+)$ exchanger. Eur J Med Chem 2003;38:547-54.

3. Haddad N, Rajan J, Nagaraja HN, Agarwal AK, Hebert LA. Usual ACE inhibitor therapy in CKD patients is associated with lower plasma aldosterone levels than usual angiotensin receptor blocker therapy. Kidney Blood Press Res 2007;30:299-305.

4. Bollensdorff C, Zimmer T, Benndorf K. Amiloride derivatives are potent blockers of KATP channels. Naunyn Schmiedebergs Arch Pharmacol 2001;364:351-8.

5. Garritsen A, Ijzerman AP, Beukers MW, Cragoe EJ Jr, Soudijn W. Interaction of amiloride and its analogues with adenosine A1 receptors in calf brain. Biochem Pharmacol 1990;40:827-34.

6. Fisher JL. Amiloride inhibition of gamma-aminobutyric acid(A) receptors depends upon the alpha subunit subtype. Mol Pharmacol 2002;61:1322-8.

7. Waldmann R, Lazdunski M. H(+)-gated cation channels: Neuronal acid sensors in the $\mathrm{NaC} / \mathrm{DEG}$ family of ion channels. Curr Opin Neurobiol 1998;8:418-24.

8. Benos DJ. Amiloride: A molecular probe of sodium transport in tissues and cells. Am J Physiol 1982;242:C131-C145.

9. Ferreira J, Santos AR, Calixto JB. Antinociception produced by systemic, spinal and supraspinal administration of amiloride in mice. Life Sci 1999;65:1059-66.

10. Zeng W, Chen X, Dohi S. Antinociceptive synergistic interaction between clonidine and oubain on thermal nociceptive tests in the rat. J Pain 2007;8:983-8.

11. Ono H, Mishima A, Ono S, Fukuda H, Vasko MR. Inhibitory effects of clonidine and tizanidine on release of substance P from slices of rat spinal cord and antagonism by alpha-adrenergic receptor antagonists. Neuropharmacology 1991;30:585-9.

12. McCarthy RJ, Kroin JS, Lubenow TR, Penn RD, Ivankovich AD. Effect of intrathecal tizanidine on antinociception and blood pressure in the rat. Pain 1990;40:333-8.

13. Kawamata T, Omote K, Kawamata M, Iwasaki H, Namiki A. Antinociceptive interaction of intrathecal alpha2-adrenergic agonists, tizanidine and clonidine, with lidocaine in rats. Anesthesiology 1997;87:436-48.

14. Nabeshima T, Matsuno K, Sugimoto A, Kameyama T. Antinociceptive activity induced by tizanidine and alpha 2-adrenoreceptors. Neuropharmacology 1987;26:1453-5.

15. Wagstaff AJ, Bryson HM. Tizanidine. A review of its pharmacology, clinical efficacy and tolerability in the management of spasticity associated with cerebral and spinal disorders. Drugs 1997;53:435-52.

16. Ouyang H, Bai X, Huang W, et al. The antinociceptive activity of intrathecally administered amiloride and its interactions with morphine and clonidine in rats. J Pain 2012;13:41-8.
17. Leppik RA, Birdsall NJ. Agonist binding and function at the human alpha(2A)-adrenoceptor: Allosteric modulation by amilorides. Mol Pharmacol 2000;58:1091-9.

18. Langerman L, Grant GJ, Zakowski M, et al. Prolongation of epidural anesthesia using a lipid drug carrier with procaine, lidocaine, and tetracaine. Anesth Analg 1992;75:900-5.

19. Tallarida RJ, Porreca F, Cowan A. Statistical analysis of drug-drug and site-site interactions with isobolograms. Life Sci 1989;45:947-61.

20. Tallarida RJ. Statistical analysis of drug combinations for synergism. Pain 1992;49:93-7.

21. Hamill OP, Lane JW, McBride DW Jr. Amiloride: A molecular probe for mechanosensitive channels. Trends Pharmacol Sci 199213:373-6.

22. Palmer LG. Epithelial Na channels: Function and diversity. Annu Rev Physiol 1992;54:51-66.

23. Sluka KA, Price MP, Breese NM, et al. Chronic hyperalgesia induced by repeated acid injections in muscle is abolished by the loss of ASIC3, but not ASIC1. Pain 2003;106:229-39.

24. Dube GR, Lehto SG, Breese NM, et al. Electrophysiological and in vivo characterization of A-317567, a novel blocker of acid sensing ion channels. Pain 2005;117:88-96.

25. Jones NG, Slater R, Cadiou H, McNaughton P, McMahon SB. Acid-induced pain and its modulation in humans. J Neurosci 2004;24:10974-9.

26. Fyfe GK, Quinn A, Canessa CM. Structure and function of the Mec-ENaC family of ion channels. Semin Nephrol 1998;18:138-51.

27. Castañeda-Corral G, Rocha-González HI, Araiza-Saldaña CI, et al. Blockade of peripheral and spinal $\mathrm{Na}+/ \mathrm{H}+$ exchanger increases formalin-induced long-lasting mechanical allodynia and hyperalgesia in rats. Brain Res 2012;1475:19-30.

28. Castañeda-Corral G, Rocha-González HI, Godínez-Chaparro B, Jiménez-Andrade JM, Granados-Soto V. Role of the spinal $\mathrm{Na}+\mathrm{H}+$ exchanger in formalin-induced nociception. Neurosci Lett 2011;501:4-9.

29. Beltrán-Villalobos KL, Ramírez-Marín PM, Cruz CAZ, DécigaCampos M. Coadministration of Tramadol and Tizanidine in an Experimental Acute Pain Model in Rat. Drug Dev Res 2014;75:4738.

30. Kameyama T, Nabeshima T, Sugimoto A, Matsuno K, Yamada S. Antinociceptive action of tizanidine in mice and rats. Naunyn Schmiedebergs Arch Pharmacol 1985;330:93-6.

31. Berenbaum MC. What is synergy? Pharmacol Rev 1989;41:93-141.

32. Clarke JD, Cragoe EJ Jr, Limbird LE. Alpha 2-adrenergic receptors regulate $\mathrm{Na}(+)-\mathrm{H}+$ exchange via a cAMP-dependent mechanism. Am J Physiol 1990;259:F977-F985.

33. Monasky MS, Zinsmeister AR, Stevens CW, Yaksh TL. Interaction of intrathecal morphine and ST-91 on antinociception in the rat: Dose-response analysis, antagonism and clearance. J Pharmacol Exp Ther 1990;254:383-92. 


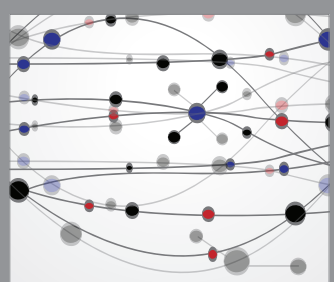

The Scientific World Journal
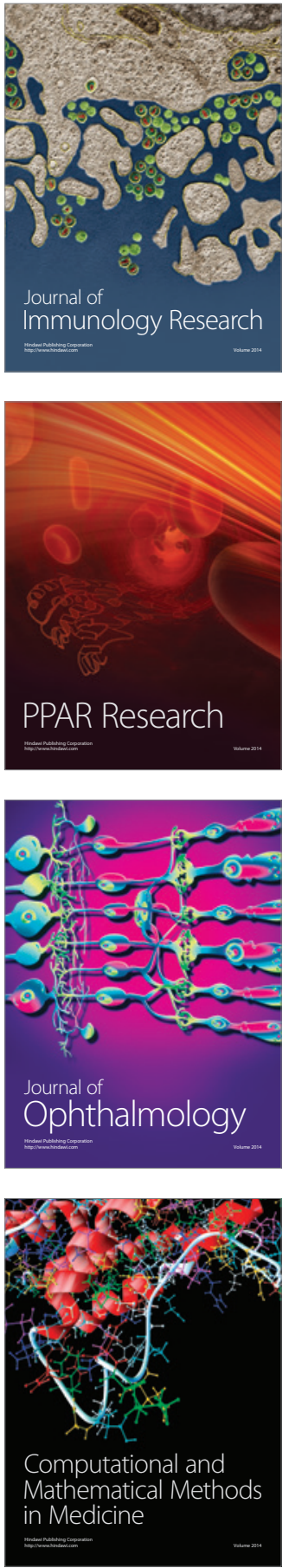

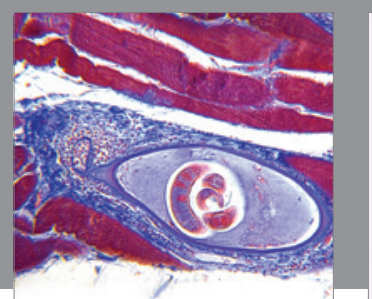

Gastroenterology Research and Practice

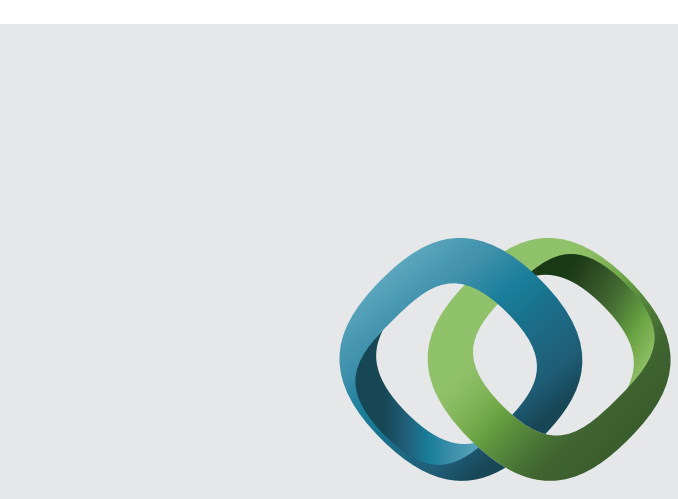

\section{Hindawi}

Submit your manuscripts at

http://www.hindawi.com
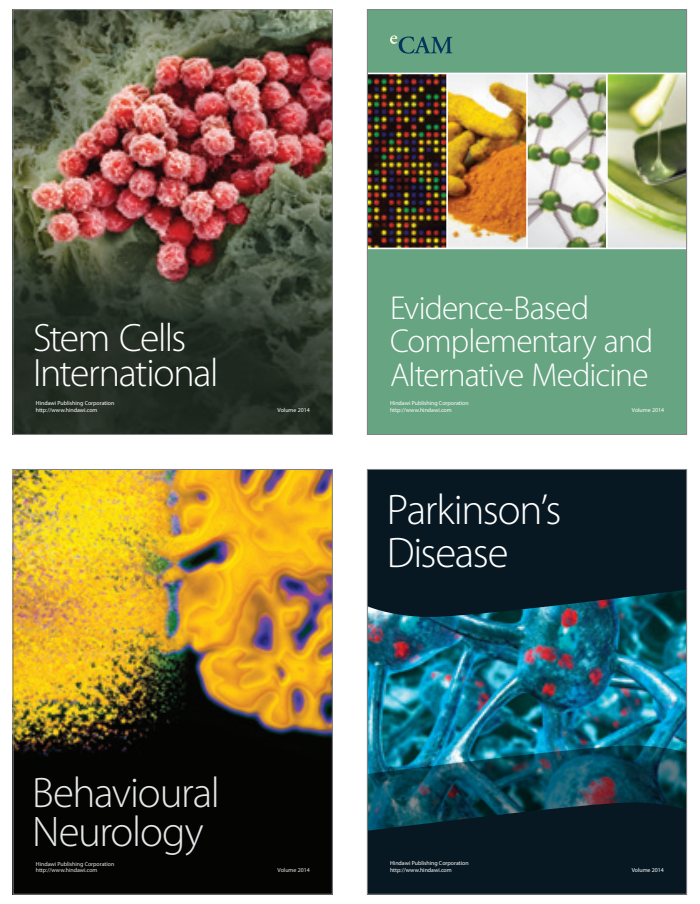
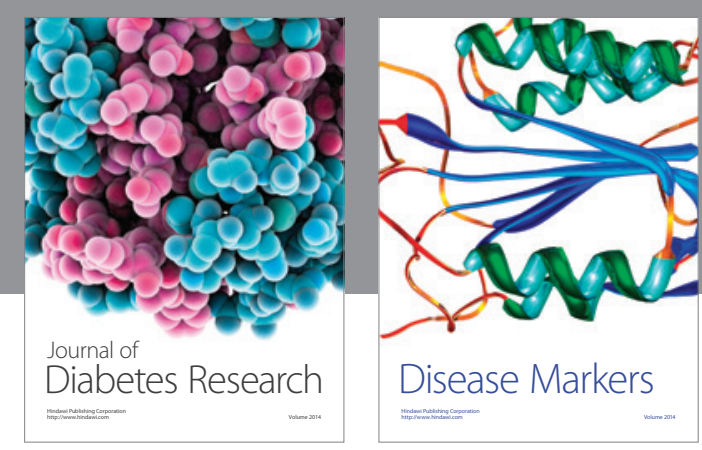

Disease Markers
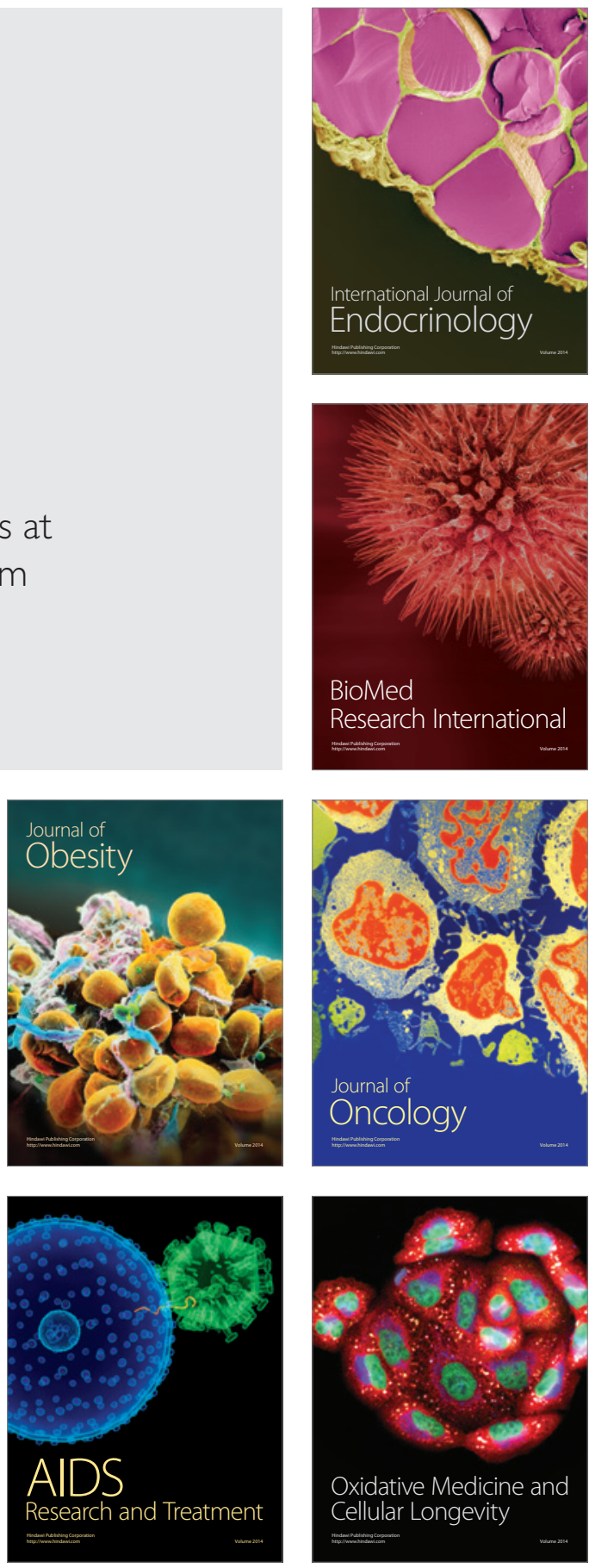